\title{
Formation of Management Teams of Educational Organizations
}

\author{
Vodneva S.N. \\ Pskov State University, \\ Pskov, Russia, \\ wodnewa@yandex.ru
}

\author{
Donina I.A. \\ Yaroslav-the-Wise Novgorod State University, \\ Veliky Novgorod, Russia, \\ doninairina@gmail.com
}

\author{
Dagaeva I.A. \\ Pskov State University, \\ Pskov, Russia \\ degava@mail.ru
}

\begin{abstract}
This article discusses the problems and prospects of introducing command administration into the management system of a modern educational organization, since this management context is the most promising for the current situation in the modern macro environment. The authors of the article conducted a study aimed at identifying the readiness of the teaching staff of schools for teamwork to implement strategic and tactical development plans. It is this trend that actualizes the increasing popularity of the creation of new pedagogical conditions and the use of pedagogical technologies, both offline and online. The authors understand a group of people connected by a common understanding of the mission, goals and management methods, capable of creating the best conditions for achieving high results for the entire group by a management team. The article analyzes the phenomenon of team-group work in general educational organizations, identifies the most significant management deficits and problems in the implementation of command management, and suggests mechanisms for their leveling. It is important to note that the authors of the article were interested not only in the substantive issues of command management, but also in the formation of the readiness of school teams to participate in the management of their educational organization. The article also considered aspects of partnership of all subjects of the educational process: students, parents, teachers, school administration, the public. The results of the research are interdisciplinary and are fully reflected in the conclusions and in the conclusion and are of interest for further statistical, pedagogical, psychological research, as well as research related to personnel management in educational organizations.
\end{abstract}

Keywords-management team, general educational organization, management deficits

\section{INTRODUCTION}

One of the features of the development of modern society is digitalization, which in management is characterized as a process of transition to new management models based on information technologies. The successful implementation of information technologies in the practice of educational management requires new competencies of all participants in the educational process: students and their parents (legal representatives), teachers, and heads of educational organizations. At the same time, all managerial competencies can be divided into two components: the first is associated with a more effective use of information technologies in the management process, the second - with the build-up of existing managerial competencies in new conditions (team building, leadership, strategic planning, etc.).

The qualifications of employees determine the success of any organization, regardless of the field of activity, and its development is largely determined by the qualifications of the management team. Many methods and principles of management are moving from the commercial sector to the field of education; educational organizations are becoming more and more diverse both in the form and in the content of educational programs, which requires a variety of managerial decisions from the head. The director and management team act as a "strategist" and "technologist" of the educational process at school, who need modern management knowledge and skills when working in conditions of limited resources.

In the context of this article, the authors would like to draw attention to the relevance of traditional management competencies in new conditions, in particular, to the competence of team building. The reality of the functioning of a modern Russian school is as follows: distance technologies, parents" requirements for informing about the educational process, the dispersion of the teaching and administrative staff of the school during remote work. This situation actualizes the formation of such a phenomenon as a management team in schools. 


\section{PRoblem Statement}

The problem of forming management teams is not new in management practice, but each time period dictates its own requirements for the qualifications of participants and the organizational conditions for its functioning. In each historical period, certain accents arise that are most significant for the functioning of management teams. At present, the world community is widely discussing the problems of managing an educational organization related to the following aspects: the organization of value-oriented management [1], business education of project team members [2,3], management of the professional development of a teacher [4], expertise of professional teacher development [5], the formation of skills for working in a virtual team $[6,7]$.

A special place in modern research is occupied by a block of articles devoted to the interaction of participants in a virtual environment, the effective use of their resource states, the leveling of conflicts [8], virtual psychological and pedagogical support of subjects of the educational process, tutoring [9], and teaching virtual coaching [10]. The issues of virtual interaction became especially relevant during the COVID-19 coronavirus pandemic, which gave rise to the impression of an unprecedented saving of resources of educational organizations, which tend to be in short supply.

The issue of limited resources has been raised for a long time and is still a relevant and discussed topic. The historical basis of this issue is considered to be, on the one hand, the inconsistency of unlimited human needs, and, on the other hand, the quantitative and qualitative limitations of resources. This is typical of both large and small economic systems. At the same time, D.L. Simon argues that there is always a "last resource" - this is "human ingenuity" and, as a consequence, resources from a limited category become limitless. The author makes the assumption that "the limitlessness of resources is associated with the limitless possibilities of a person for improvement" [11] and confirms this with examples from entrepreneurship, when, upon exhaustion of some resources, "human ingenuity" develops new technologies for using others.

The resources of the educational system include everything that is used in the educational process: material, financial, labor, intellectual, informational, etc. We can talk about the impact on the quality of the educational process to the extent that the available resources of an educational organization meet modern requirements (technical, technological). In a situation of strict regulation of material and financial resources, the main source of development of an educational organization is precisely labor resources with their intellectual potential and abilities [12, 13]

It should be noted that management of an educational organization is a special type of professional activity that includes many specific functions, which requires collective efforts to achieve the overall goals of the organization.

Thus, in modern conditions of the multitasking activity of the head of a general educational organization and limited resources, it becomes necessary to introduce a team approach to school management. It is by combining the intellectual potential of the management team that the synergistic effect is fully manifested, which can be considered as a factor of "human ingenuity" in various issues of managing an organization, and this, in turn, will expand the boundaries of labor resources, which will undoubtedly lead to more effective management educational organization.

A team is a collective of employees who are united not only by common goals, but also by similar business and moral principles. Together with V. Larionova, N. Stepanova, O. Bashorina [14], the management team of an educational organization will be understood as a group of persons associated with a common understanding of the mission, goals and methods of school management, who are focused on jointly solving school problems and are able to create the best conditions for achieving high results of the whole team.

A well-formed team is a tool that ensures the effective work of the entire organization.

It is customary to distinguish the following types of team formation in business [15]:

- goal-setting, when the main criterion for team formation is the achievement of a goal (strategic, operational), which allows developing the best ways to solve the tasks;

- interpersonal, focused on improving intragroup interpersonal relationships and communication;

- role-based, implies a discussion and negotiation among team members regarding their team roles, which are determined by their functionality (subject matter of activity), way of working and contribution to the team's work. R.M. Belbin [16] identifies such roles as, actionoriented roles: motivator, performer, "informer"; social roles: idea generator, resource explorer, mastermind; intellectual roles: analyst, specialist. I. Adizes [17] identifies the team roles: manufacturer, administrator, entrepreneur, integrator, based on the idea of the life cycle of the organization, where each life stage of the organization is characterized by the dominance of any role;

- problem-oriented, when in the course of teamwork it is supposed to solve problems in a more efficient way through pre-planned meetings with a consultant. With such work, there is a consistent development of the solution to team tasks.

Obviously, teams are not created from scratch (with the exception of newly created organizations). According to R.M. Belbin, more often a team is formed of employees who perform the corresponding duties in their departments. They become team members due to their functions [16].

At the present stage, education management has the character of a rigid hierarchy. However, today the vertical of power is not conducive to the development of educational structures. When team management is introduced, the vertical management hierarchy will stop at the school level and move into the category of "horizontal" management. The leader and deputies will definitely be part of the team, while the leader is appointed to the position, and then tries to choose a team "for themselves". With this approach, two ways of forming a team can be distinguished: natural (based on the commonality of goals, motives, etc.) and administrative (based on the will of 
the leadership). In any way of forming a team, the roles of its members are determined, only in the first case, taking into account the preferences and desires of employees, in the second case - at the will of the administration, mainly taking into account the competence of employees, and its preferences recede into the background. According to T.M. Darkhanova, the relationship between team members will be built in different ways, but in any case, the final decision on the composition of the team is made by the management [12].

During its existence, each team will go through the path of its development, starting with the working group and reaching the level of an effective team. A feature of teamwork is that each employee performs their personal and team roles, the balance between which ensures a comfortable working environment. Therefore, when assigning roles, it is necessary to consider the strengths and weaknesses of the activities of each employee, which will make it possible to organize the work of the team more effectively. In this case, the leader needs to move from the model of "permanent distribution of roles that occurs when hiring" to the model of "taking different roles for the problem", as well as in the leadership model to activities from leadership "by instruction" to leadership based on motivation, but directly in matters of motivation from "responsibilities" to "team spirit" and "satisfaction from victories" [18].

Analysis of trends in the development of modern society and education as a branch of the economy, as well as an analysis of modern research devoted to this problem, showed that in the practice of management of educational organizations today there is a problem of the readiness of subjects of the educational process to create management teams, participate actively in their activities and manage them.

\section{RESEARCH QUESTIONS}

3.1. Are there any managerial deficits in the general education organization today?

3.2. Are modern leaders of educational organizations ready to work in a management team?

3.3. What are the expectations of school leaders and deputies from teamwork?

\section{PURPOSE OF THE STUDY}

The purpose of this study is to identify the degree of readiness of the director corps for teamwork, which ensures a high level of managerial decision-making in conditions of limited resources and the specifics of the functionality of the head of a general educational organization.

\section{RESEARCH METHODS}

The main research methods were the following: observation, analogy method, survey (questionnaire survey), system analysis.

\section{FINDINGS}

General educational organizations of the city of Pskov (Russia) acted as a testing ground for finding answers to the research questions posed, in which 87 leaders and their deputies were interviewed.
As survey results show, a large administrative burden on the head, an increase in "paper" work, a constantly changing external environment necessitates team management work in an educational organization. The study confirms that $90.8 \%$ of respondents note the presence of professional teams in their educational institutions, only $2.2 \%$ of respondents note that teams are formed depending on the goal and specific conditions. The presence of one team was noted by $45 \%$ of the respondents, $23 \%$ indicated the presence of two teams, $20.7 \%$ chose the option of having three teams. Moreover, $5.7 \%$ of respondents indicated that there are no teams, and $1.1 \%$ do not know about their existence, even if they exist. Among directors of general education organizations, 11 managers singled out one team, 8 managers singled out two teams, one respondent answered that teams are formed as needed and one respondent answered that teams are formed depending on the goals and objectives.

However, when defining the topic of the team's work, $28 \%$ of the respondents noted that there was no specific topic. An analysis of the answers about the topic of the team's work showed that $27 \%$ are given to methodological work, $15 \%$ of teams are working on a program for educating students, $10 \%$ are dealing with management and development of an educational organization. $9 \%$ of teams are engaged in the quality of education, including the issues of the intra-school system for assessing the quality of education (ISSAQE). The structure of answers to this question is shown in the Figure 1.

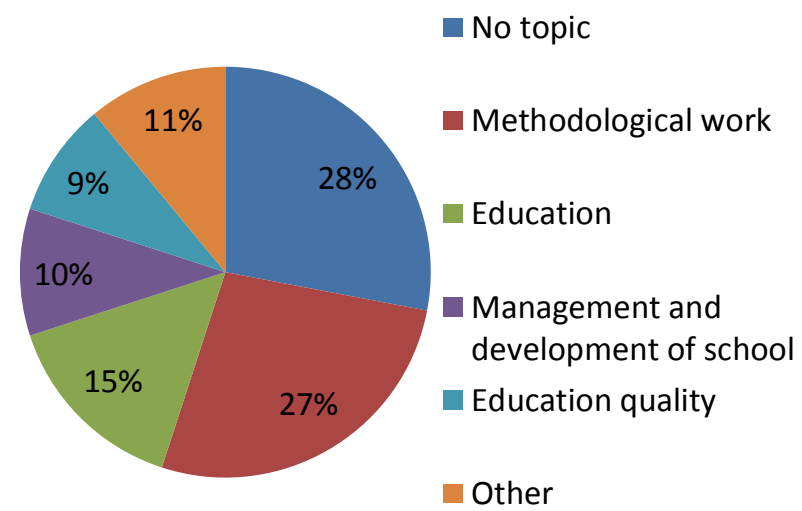

Fig. 1. The structure of the answers of the deputy heads of educational organizations to the question about the topics of team work

When correlating the answers about the presence of teams and their thematic work, a discrepancy is revealed: more than $90 \%$ of respondents note that teams have been created, while a quarter of the respondents $(25.24 \%)$ cannot formulate the topics the team is working on; this indicates that employees feel the presence of a team and are ready to work in a team but believe that teamwork does not need a specific topic. The respondents who gave such an answer are more likely to belong to the group of respondents who indicated that the topic depends on the circumstances, i.e., the team is constant and ready to solve any problems that arise. 
We also note that the priorities of teamwork among managers and their deputies, overall, have the same orientation, which, in turn, may indirectly indicate a similar understanding of the problems and tasks facing schools.

The work of many managers is based on an intuitive level (which confirmed the non-recognition of managerial deficiencies and the lack of managerial education in the framework of the survey) and leads to the fact that the social status of an educational organization is formed based on the personality of its leader. But as soon as such a leader leaves and a new one comes, the "rules of the game" within the organization, in relations with the external environment, change dramatically, which often leads to negative consequences. In addition, a modern leader of any organization is characterized by a situation of solving many tasks and performing functions that are often not directly related to the existing specialized education. The sphere of issues and tasks of a modern school leader includes:

- development of a general strategy for the educational organization;

- development, approval and implementation of the plan of financial and economic activities of the organization, drawing up its budget;

- management of the organization's resources (material, financial, labor, etc.);

- establishing and maintaining contacts with external stakeholders, both individuals and legal entities;

- defending the interests of the organization in higher organizations, government bodies, management, and regulation, etc.

The results of the survey showed that, in the opinion of managers, the subject of the team's work is clear to them. The structure of the answers of the heads of educational organizations about the topic of the work of the management team of a general educational organization is shown in the Figure 2.

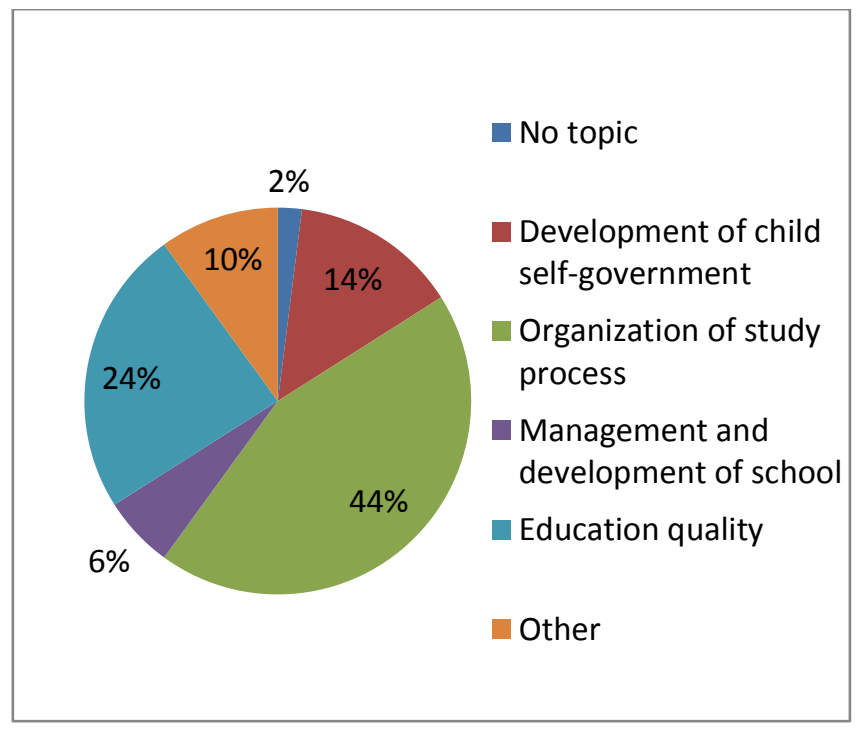

Fig. 2. The structure of the answers of the heads of educational organizations to the question about the topics of team work

Considering the large proportion of the lack of the topic of teamwork, however, almost all respondents formulated the desired areas of work in the future: work to improve the quality of education (internal and external assessment), documentary support of the educational process, methodological work, quality management of education, personnel management, spiritual and moral development of students. Separate answers on the issue of determining the topic of work included such areas as: preparation of grant documentation, support of children with disabilities, work with disadvantaged families, socialization of children, work with poorly motivated children, organization of additional education for children.

The survey also showed that the heads of educational organizations would like to see the work of the management team, first of all, on the problem of improving the quality of education (internal and external assessment) $-28.5 \%$ of responses, on the management and development of the educational organization, as well as on the issues of personnel management in conditions of its deficit $-23.8 \%$ of answers. With the development of an educational organization, the issue of its status is closely intertwined; $8 \%$ of the respondents from among the heads of general educational organizations are interested in its formation. The choice of leaders includes such topics as, private issues related to the project and scientific activities of teachers and students, work with poorly motivated children and their parents.

It should also be noted that the expressed wishes are not grouped by educational organizations, i.e., those wishing to deal with one topic are likely to work in different schools. Therefore, it is impossible to say unequivocally that a particular theme was chosen by the team of one school. This requires additional research. But this situation indicates that it is possible to build network interaction between different educational organizations.

\section{CONCLUSION}

The analysis of scientific literature and the data of the study allows us to conclude that management teams are a promising tool for the management of a general education organization, and their potential is its resource. Meanwhile, the managerial competence of the subjects of the educational process is currently insufficiently formed. As pedagogical technologies of its formation, the following can be used: corporate training of pedagogical collectives of schools, network interaction between different educational organizations, creation of virtual teams of different ages, coaching support of the management process.

\section{REFERENCES}

[1] S. Trapitsin, Z. Apevalova, N. Sokolova and I. Trofimova, "Valuebased management of educational organization", in Proceedings of the 9th Professional Culture of the Specialist of the Future (PCSF 2019), 2019, vol. 73, pp. 905-916. (In Russ.). DOI: https://doi.org/10.15405/epsbs.2019.12.95

[2] I. Donina and E. Vovk, "Training Staff Of Project Teams For Modern Business", in Proceedings of the Modern Tools for Sustainable Development of Territories. Special Topic: Project Management in the Regions of Russia (MTSDT 2019), 2019, vol. 7, pp. 107-113. (In Russ.). DOI: https://doi.org/10.15405/epsbs.2019.12.05.13

[3] T. Anisimova and I. Shpilevaya, "Business technologies in education" [Biznes-tehnologii v obrazovanii]. Concept [Konzept], 2015, vol. 7. (In 
Russ.). Rerieved from https://cyberleninka.ru/article/n/biznes-tehnologiiv-obrazovanii

[4] I. Burlakova, A. Kirsanov and A. Nikolaeva, "Management of professional development of teachers in higher education", in Proceedings of the Social and Cultural Transformations in the Context of Modern Globalism (SCTCMG 2019), 2019, vol. 76, pp. 536-543. (In Russ.). DOI: https://doi.org/10.15405/epsbs.2019.12.04.73

[5] O. Urban, N. Demchuk, T. Burnysheva, I. Isakova and K. Burnyshev, "Regional vocational education system in peer review", in Proceedings of the Social and Cultural Transformations in the Context of Modern Globalism (SCTCMG 2019), 2019, vol. 76, pp. 3243-3249. (In Russ.). DOI: https://doi.org/10.15405/epsbs.2019.12.04.436

[6] H. Bin, S. Jing and O.H. Olav, "Cross-cultural Teleworking Virtual Team and Its Management Cross-cultural Teleworking Virtual Team and Its Management", in Proceedings of the 5th International Symposium for Corporate Governance, Books 1 AND 2. 2009, pp. 138-145.

[7] C. Beise, T. Carte and Ch. Vician, "A Case Study of Project Management Practices in Virtual Settings: Lessons from Working in and Managing Virtual Teams", Data base for advances in information systems, 2010, vol. 4, pp. 75-97.

[8] M. Wahyudhy and W. Salamah, "The Effect of Team Relationship Conflict and Team Conflict Management on Team Performance: The Role of Team Cohesion Mediation", in Proceedings of the 32nd Conference of the International-Business-Information-ManagementAssociation (IBIMA), VISION 2020: sustainable economic development and application of innovation management, 2018, pp. 6047-6051.

[9] D. Galindo, R. Sierra and C. Carrasco, "Profile of the tutor for a correct accompaniment to the students in the course in Social Responsibility", La Revista Dilemas Contemporáneos: Educación, Política y Valores, 2017, vol. 5(1). (Espanola). Rerieved from http://www.dilemascontemporaneoseducacionpoliticayvalores.com/

[10] R.D. Martin, A.M.C. Chust and M.L.F. Rodriguez. "Implementing educative coaching in virtual university, a personal development tool", Innoeduca-international journal of technology and educational innovation, 2018, vol. 4(2), pp. 150-158. DOI: http://dx.doi.org/10.24310/innoeduca.2018.v4i2.4930

[11] E. Makarova, "On the issue of limited economic resources" ["K voprosu ob ogranichennosti ekonomicheskih resursov"]. Bulletin ChelSU [Vestnik ChelGU], 2016, vol. 6(388). (In Russ.). Rerieved from https://cyberleninka.ru/article/n/k-voprosu-ob-ogranichennostiekonomicheskih-resursov

[12] T. Darhanova, "Organizational and pedagogical prerequisites for the formation of a teaching staff in a market economy" ["Organizatsionnopedagogicheskie predposylki formirovaniya pedagogicheskogo kollektiva v usloviyah rynochnoy ekonomiki"]. Bulletin BSU [Vestnik BGU], 2016, vol. 4, pp. 180-183. (In Russ.). Rerieved from https://cyberleninka.ru/article/n/organizatsionno-pedagogicheskiepredposylki-formirovaniya-pedagogicheskogo-kollektiva-v-usloviyahrynochnoy-ekonomiki

[13] J. Turner, T. Zimmerman and J. Allen, "Teams as a sub-process for knowledge management", Journal of Knowledge Management, 2012, vol. 16(6), pp. 963-977.

[14] V. Larionova, N. Stepanova and O. Bashorina, "The function of management studies and researchers in viable managerial decisionmaking", in Proceedings of the 19th Professional Culture of the Specialist of the Future (PCSF 2019), 2019. (In Russ.). DOI: https://doi.org/10.15405/epsbs.2019.12.100

[15] E. Solodova, D. Kalmykova and K. Polupan. "Team building as a modern way of human resource management" ["Komandoobrazovanie kak sovremennyy sposob upravleniya chelovecheskimi resursami"]. Samara University Bulletin. Economics and Management [Vestnik Samarskogo universiteta. Ekonomika i upravlenie], 2018, vol. 9(4), $\begin{array}{llll}\text { pp. 67-71 (In } & \text { Russ.). } & \text { Rerieved }\end{array}$ https://cyberleninka.ru/article/n/komandoobrazovanie-kaksovremennyy-sposob-upravleniya-chelovecheskimi-resursami

[16] V. Demyanenko, "Team rols" ["Komandnye roli"]. HR-Portal [Portal Upravlenie ismeneniyami], 2020. (In Russ.). Rerieved from http://ibcm.biz/командные-роли-р-белбин/

[17] V. Demyanenko, "Timing of change before it occurs - the life cycle of an organization (I.Adizes)" ["Opredelenie vremeni izmenenii do ih nastupleniya - shisnennyi tsikl organisatsii (I.Adizes)"]. HR-Portal [Portal Upravlenie ismeneniyami], 2020. (In Russ.). Rerieved from http://ibcm.biz/определение-времени-изменений-до-их-н/

[18] W. Ariratana, S. Sirisookslip and T.K. Ngang, "Development of Leadership Soft Skills Among Educational Administrators", Procedia Social and Behavioral Sciences, 2015, vol. 186, pp. 331-336. DOI: https://doi.org/10.1016/j.sbspro.2015.04.016 